\title{
PROSES PUBLIC RELATIONS DALAM PROGRAM LAYAR TANCAP UNTUK SEMUA OLEH SCTV
}

\author{
Andika Pakaradena ${ }^{1}$, Hanny Hafiar ${ }^{2}$, Aat Ruchiat Nugraha ${ }^{3}$ \\ ${ }^{1,2,3}$ Program Studi Hubungan Masyarakat, Fakultas Ilmu Komunikasi, Universitas Padjadjaran
}

\begin{abstract}
ABSTRAK
Program Layar Tancap Untuk Semua dilaksanakan oleh Departemen Program Communication SCTV pada 9 Desember 2017 di Sukoharjo, Jawa Tengah. Program ini dilaksanakan berdasarkan Proses Public Relations menurut Cutlip, Center, dan Broom. Metode yang digunakan dalam penelitian kualitatif ini adalah metode deskriptif dengan paradigma post-positivisme. Teknik pengumpulan data dengan wawancara, observasi, dan studi kepustakaan. Simpulan dari penelitian ini adalah pada tahap defining the problem, analisis situasi yang dilakukan Departemen Program Communication peneliti masih kurang mengetahui analisis situasi yang sesungguhnya dilakukan. Pada tahap planning and programing, dilakukan perencanaan dengan baik. Pada tahap action and communicating, dilakukan dengan baik berkoordinasi dengan Event Organizer dan Departemen Marketing Communication. Pada tahap evaluating the program, belum dilakukan dengan baik karena proses evaluasi hanya dilakukan dengan mengukur kehadiran pengunjung. Saran dari peneliti adalah pada tahap penelitian, sebaiknya analisi situasi yang dilakukan tidak hanya melihat secara internal tetapi juga secara eksternal. Kemudian untuk proses riset sebaiknya tidak hanya dilakukan dengan sebatas diskusi, tetapi juga bisa dilakukan dengan setiap pernyataan masalah berisi ukuran konkrit dari situasi masalah berdasarkan penelitian yang obyektif. Pada tahap pelaksanaan, peneliti menyarankan agar penyusunan cue card dan rundown ditambahkan lagi konten mengenai pesan SCTV sebagai Rumah Film Indonesia agar semakin meningkatkan awareness masyarakat. Pada tahap evaluasi, sebaiknya evaluasi yang dilakukan dengan menggunakan metode yang memiliki output lebih terukur seperti survey dengan kuisioner untuk melihat keberhasilan program apakah tujuan yang ingin dicapai sudah tercapai atau belum.
\end{abstract}

Kata-kata Kunci: Awareness; Layar Tancap Untuk Semua; Program; Proses Public Relations; SCTV

\section{PROCESS OF PUBLIC RELATIONS IN LAYAR TANCAP FOR ALL PROGRAM BY SCTV}

\begin{abstract}
Layar Tancap Untuk Semua Program held by Department of Program Communication SCTV on $9^{\text {th }}$ December 2017 at Sukoharjo, Central Java. This program implemented based on the concept of Public Relations Process by Cutlip, Center, and Broom. The method used in this qualitative research is descriptive method with post-positivism paradigm. Technique of collecting data by interview, observation, and literature study. The conclusion of this research is at the defining the problem stage, situation analysis conducted by Program Communication Department is still lack of knowing the actual situation analysis done. In the planning and programming stage, planning is done well. At the action and communicating stage, it is done well in coordination with Event Organizer and Marketing Communication Department. In the evaluating the program stage, it has not been done well because the evaluation process is only done by measuring the presence of visitors. Suggestions from researcher are at the stage of research, should the situation analysis is done not only see internally but also externally. Then for the research process should not only be done with a limited discussion, but also can be done with each problem statement contains a concrete measure of the problem situation based on objective research. At the implementation stage, the researcher suggested that the preparation of cue card and rundown added more content about SCTV message as Rumah Film Indonesia in order to increase awareness of society. At the evaluation stage, evaluation should be done using a method that has a more measurable output such as a survey with a questionnaire to see whether the program's success achieved goals have been achieved or not.
\end{abstract}

Keywords: Awareness; Layar Tancap Untuk Semua; Program; Public Relations Process; SCTV

Korespondensi: Andika Pakaradena. Program Studi Hubungan Masyarakat, Fakultas Ilmu Komunikasi, Universitas Padjadjaran, J1. Raya Bandung-Sumedang Km. 21, Sumedang.

Email: pakaradena@gmail.com 


\section{PENDAHULUAN}

Program Layar Tancap Untuk Semua merupakan program off-air yang terdiri dari senam massal, pertunjukan musik organ tunggal, permainan dan kuis interaktif berhadiah, pembagian doorprize dan puncaknya adalah penayangan film panjang nasional dan film pendek pemenang festival film pendek nasional di ruang terbuka. Program Layar Tancap Untuk Semua merupakan program yang awalnya dibuat sebagai bagian dalam rangkaian kegiatan ulang tahun SCTV yang ke-26 pada tahun 2016.

Program Layar Tancap Untuk Semua diadakan sebagai salah satu dukungan SCTV terhadap peredaran film nasional dengan mengakomodir kebutuhan masyarakat untuk menonton film nasional secara langsung, khususnya bagi mereka yang di daerahnya belum memiliki sarana bioskop. Hal ini sejalan dengan pesan yang ingin disampaikan oleh SCTV kepada masyarakat bahwa SCTV adalah Rumah Film Indonesia. Hal ini dituturkan oleh Head of Program Communication SCTV, Bapak Verno Nitiprodjo:

"Kita ingin buat acara sebagai lokomotif program SCTV yakni Rumah Film Indonesia. Dari situlah kami sepakat untuk membuat program Layar Tancap Untuk Semua dengan tujuan memberikan awareness ke masyarakat bahwa SCTV adalah Rumah Film Indonesia."
SCTV ingin menyampaikan pesan sebagai Rumah Film Indonesia. Hal ini telah lama dilakukan SCTV yang dibuktikan dengan menyajikan program-program seperti menayangkan film televisi nasional, program Sinema Wajah Indonesia, sinema elektronik serta festival film tingkat nasional secara konsisten. Namun upaya-upaya tersebut dirasa SCTV masih kurang dalam mengubah mindset masyarakat terhadap SCTV sebagai Rumah Film Indonesia, sehingga diperlukan adanya upaya lain dimana dalam hal ini ialah strategistrategi terbaru dari SCTV. Salah satu strategi terbaru dari SCTV dalam memosisikan diri sebagai stasiun televisi film nasional adalah dengan mengadakan program bertajuk Layar Tancap Untuk Semua yang bertujuan untuk meningkatkan awareness masyarakat terhadap SCTV sebagai Rumah Film Nasional.

Dalam edisi Desember 2017 lalu, program Layar Tancap Untuk Semua diadakan di Lapangan Cangkol, Kel. Bekonang, Kec. Mojolaban, Kab. Sukoharjo. Program Layar Tancap Untuk Semua kali ini tepatnya diadakan pada hari Sabtu, 9 Desember 2017 yang berlangsung mulai pukul 15.00 WIB hingga pukul 23.00 WIB.

Sebelum program Layar Tancap Untuk Semua diselenggarakan, pihak SCTV terlebih dahulu melakukan survey ke lokasi sekaligus koordinasi dengan pemerintah daerah dan aparat setempat mengenai perizinan. Kemudian pihak SCTV melakukan promosi program Layar Tancap Untuk Semua baik secara above 
the line dengan mempromosikannya di media televisi, radio dan surat kabar lokal juga secara below the line dengan mempromosikannya menggunakan sarana mobil keliling dilengkapi pengeras suara dan pembagian flyer kepada masyarakat sekitar yang didalamnya telah tercantum kupon doorprize untuk menarik minat para calon pengunjung.

Pada program Layar Tancap Untuk Semua yang telah dilaksanakan Desember 2017 lalu, selain penayangan film panjang nasional dan film pendek pemenang kompetisi film pendek nasional, diadakan pula acara senam massal yang diikuti ratusan peserta pada sore hari. Terdapat pula acara hiburan berupa pertunjukkan musik organ tunggal yang membuat masyarakat semakin tertarik untuk datang. Tidak lupa juga kuis dan pembagian hadiah doorprize yang membuat masyarakat semakin antusias mengikuti jalannya program Layar Tancap Untuk Semua.

Untuk film panjang nasional yang ditayangkan dengan media layar tancap kali ini adalah film Hangout karya Raditya Dika, dengan pertimbangan bahwa film tersebut masih baru, yakni dirilis pada tahun 2016 dan termasuk ke dalam film blockbuster. Untuk film pendek yang ditayangkan dengan media layar tancap kali ini adalah film Njuk Piye yang merupakan pemenang kategori Film Komedi dalam kompetisi Indonesian Short Film Festival pada tahun 2015 .

Seusai pelaksanaan program Layar Tancap Untuk Semua, pihak SCTV pun kemudian melakukan evaluasi berupa pembuatan laporan kegiatan. Di dalam laporan kegiatan selain terlampir rundown dan observasi selama jalannya acara berlangsung, terdapat juga masukan dari masyarakat yang mayoritas mengharapkan program ini diadakan kembali di wilayah mereka. Harapan masyarakat yang tinggi tersebut disebabkan tidak adanya akses bioskop dan minimnya hiburan umum di wilayah mereka.

Proses Public Relations dalam program Layar Tancap Untuk Semua pun jelas menarik perhatian peneliti, bagaimana proses yang dilakukan oleh Departemen Program Communication dalam program Layar Tancap Untuk Semua mulai dari riset hingga evaluasi karena program ini dianggap efektif dan mendapat respon positf sehingga secara rutin dilaksanakan setiap bulan.

Meskipun demikian, terdapat poin-poin dari tahapan proses Public Relations yang belum dijalankan secara optimal oleh Departemen Program Communication. Dimulai dari tahapan riset yang dilakukan oleh Departemen Program Communication dengan memikirkan pembuatan sebuah acara sebagai lokomotif program SCTV yakni Rumah Film Indonesia. Dari situlah Departemen Program Communication sepakat untuk membuat program Layar Tancap Untuk Semua dengan tujuan memberikan awareness ke masyarakat bahwa SCTV adalah Rumah Film Indonesia.

Kemudian dari tahapan perencanaan yang dilakukan oleh Departemen Program Communication. Pertama adalah memikirkan akan membuat event ini semenarik mungkin, memikirkan event apa yang menarik dan sesuai dengan program SCTV Rumah Film Indonesia, 
maka muncul program Layar Tancap Untuk Semua. Yang kedua yakni tampilan dari event ini agar masyarakat tertarik seperti pemasangan lampion, sound system yang mumpuni, lalu frame layar yang menarik. Ketiga adalah konten, mulai dari pemilihan tenant booth siapa saja selain sponsor, juga memilih UMKM yang menjual makanan sesuai dengan pertunjukan layar tancap sehingga semakin menguatkan memori masyarakat ketika bernostalgia di program Layar Tancap Untuk Semua, kemudian pemilihan MC dan yang penting adalah penyusunan rundown, karena ramai atau tidaknya sebuah event tergantung dari urutan acara yang dilaksanakan dalam event tersebut. Terakhir adalah perhitungan bujet/budgeting.

Dari tahapan aksi dan komunikasi yang dilakukan oleh Departemen Program Communication yakni membuat flyer, poster, spanduk, kemudian juga mempublikasikan di media sosial. Kemudian bekerja sama dengan radio-radio lokal setempat untuk mempromosikan program Layar Tancap Untuk Semua. Juga bekerja sama dengan pemerintah daerah setempat untuk perijinan dan juga promosi program Layar Tancap Untuk Semua.

Kemudian mengunjungi lokasi saat malam $\mathrm{H}-1$, kemudian paginya tetap berpromosi keliling untuk memberitahu masyarakat kalau nanti sore akan diadakan program Layar Tancap Untuk Semua. Kemudian acara dimulai, dari sore dimulai dengan mengadakan senam massal. Kemudian mengikuti rundown yang telah dibuat, meskipun nanti seringkali terdapat miss saat berjalannya acara, tinggal bagimana panitia pelaksana menyesuaikan waktu agar rundown tetap berjalan dan waktu sesuai yang telah ditentukan yakni hanya sampai pukul 23.00 .

Terakhir adalah tahapan evaluasi yang dilakukan oleh Departemen Program Communication yaitu pertama mengevaluasi jumlah crowd. Kemudian yang kedua adalah mengetes tingkat antusiasme masyarakat dengan mengadakan doorprize. Karena selain sebagai penarik perhatian masyarakat, doorprize juga dapat mengetes dengan contoh doorprize paling besar biasanya ada di urutan terakhir, namun ketika dipanggil hingga 5 orang tidak ada yang mengklaim, berarti ada yang kurang dari pelaksanaan event ini.

Adapun tujuan dari penelitian ini adalah untuk mengetahui riset dan perencanaan yang dilakukan oleh Departemen Program Communication SCTV sebelum melaksanakan program, serta pelaksanaan dan evaluasi setelah melaksanakan program Layar Tancap Untuk Semua.

\section{TINJAUAN PUSTAKA}

Menurut Cutlip, Center dan Broom proses manajemen Public Relations sepenuhnya mengacu kepada pendekatan manajerial. Proses perencanaan ini dapat dilakukan melalui "Empat Tahapan atau Langkah-langkah Pokok" yang menjadi landasan atau acuan untuk pelaksanaan program kerja kehumasan adalah sebagai berikut: 
Mendefinisikan Masalah atau Peluang (Defining Public Relations Problem). Tahap pertama meliputi memperhatikan dan mengawasi pengetahuan, opini, sikap, dan tingkah laku pihak-pihak yang berhubungan dan terpengaruh akan aksi dan kebijakan dari suatu organisasi. Ini merupakan fungsi intelegensi dan organisasi. Tahap ini merupakan fondasi dari langkah-langkah berikutnya dalam proses penyelesaian masalah dengan menentukan “Apa yang terjadi sekarang?” (Cutlip, Center, \& Broom, 2011).

Perencanaan dan Pemrograman (Planning and Programming). Informasi yang dikumpulkan pada tahap pertama digunakan untuk menentukan program untuk publik, objective (sasaran), strategi aksi dan komunikasi, taktik dan tujuan. Tahap kedua ini meliputi menerjemahkan temuan-temuan dalam tahap pertama ke dalam kebijakan dan program organisasi. Tahap ini berupaya menjawab "Berdasarkan dari apa yang kita ketahui mengenai situasi, apa yang harus kita rubah, lakukan dan katakan?" (Cutlip et al., 2011).

Mengambil

$$
\text { Tindakan }
$$

dan

Berkomunikasi (Taking Action and Communication). Tahap ketiga melibatkan pengimplementasian program aksi dan komunikasi yang telah dirancang untuk mencapai objective tertentu bagi tiap publik dan untuk mencapai tujuan program. Pertanyaan yang harus dijawab dalam taha ini adalah "Siapa yang harus mengatakannya, kapan, dimana, dan bagaimana?" (Cutlip et al., 2011).

Mengevaluasi Program (Evaluating the program). Tahap akhir dalam proses ini meliputi penilaian terhadap persiapan, implementasi, dan hasil program. Penyesuaian atau perubahan dibuat ketika program diimplementasikan berdasarkan evaluasi atas apakah program berjalan lancar atau tidak. Program dilanjutkan atau diberhentikan setelah mempelajari "Bagaimana hasil dari upaya yang kita lakukan?" (Cutlip et al., 2011).

Menurut Scott M. Cutlip, Allen H. Center, dan Glen M. Broom (2000), dalam buku Ardianto (2011:8), definisi Public Relations yakni: Public Relations is the management function which evaluate public attitudes, identifies the policies and prochedures of an individual or an organization with the public interest, and plans an executes a program of action to earn public understanding an acceptances (Public Relations adalah fungsi manajemen yang menilai sikap-sikap publik, mengidentifikasi kebijakan-kebijakan dan prosedur-prosedur dari individu atau organisasi atas dasar kepentingan publik dan melaksanakan rencana kerja untuk memperoleh pengertian dan pengakuan publik) (Cutlip et al., 2011).

David Aaker menyatakan: "Brand Awereness is the ability of a potential buyer to recognize or recall that a brand is a member of a certain product category”. Maksudnya adalah Brand Awareness merupakan kemampuan dari pelanggan potensial untuk mengenali atau mengingat bahwa suatu merek termasuk ke dalam kategori produk tertentu (Handayani, 2010).

Brand Awareness memiliki indikator sebagai berikut (Handayani, 2010): 
Unaware of brand. Pada tahap ini, pelanggan belum merasa yakin apakah mereka sudah mengenali mereka yang disebutkan atau belum. Contohnya adalah ketika pengunjung merasa tidak mengenal SCTV sebagai Rumah Film Indonesia.

Brand Recognition. Di tahap ini, pelanggan sudah mampu mengidentifikasi merek yang disebutkan. Misalnya ketika masyarakat mulai mengenal SCTV sebagai Rumah Film Indonesia.

Brand Recall. Pelanggan mampu mengingat merek tanpa stimulus. Contohnya ketika pengunjung mulai mengenal SCTV sebagai Rumah Film Indonesia tanpa diberi pancingan dengan kata kunci "Film Nasional".

Top of mind. Pada tahapan ini pelanggan mengingat merek sebagai yang pertama kali muncul di pikiran saat berbicara mengenai kategori produk tertentu. Contohnya ketika masyarakat mengingat SCTV sebagai Rumah Film Indonesia sebagai hal pertama yang terlintas dibenak mereka, ketika mereka membicarakan hal yang menyangkut perfilman nasional.

Program Layar Tancap Untuk Semua merupakan sebuah program dari Departemen Program Communication yang merupakan festival pertunjukan layar tancap dengan menayangkan film Indonesia berkualitas dan terkini kepada masyarakat sebagai apresiasi SCTV kepada pemirsa setia SCTV.

Program Layar Tancap Untuk Semua diadakan di Lapangan Cangkol, Jl. Mayor
Ahmadi, Kel. Bekonang, Kec. Mojolaban, Kab. Sukoharjo, Jawa Tengah. Diadakan pada Sabtu, 9 Desember 2017 dari pukul 15.00 WIB hingga pukul 23.00 WIB.

Bermula dari J1. Darmo Permai, Surabaya, Agustus 1990, siaran SCTV diterima secara terbatas untuk wilayah Gerbang Kertosusila (Gresik, Bangkalan, Mojokerto, Surabaya, Sidoardjo dan Lamongan) yang mengacu pada izin Departemen Penerangan No. 1415/RTF/K/IX/1989 dan SK No. 150/SP/DIR/TV/1990. Satu tahun kemudian, 1991, pancaran siaran SCTV meluas mencapai Pulau Dewata, Bali dan sekitar.

Baru pada tahun 1993, berbekal SK Menteri Penerangan No 111/1992 SCTV melakukan siaran nasional ke seluruh Indonesia. Untuk mengantisipasi perkembangan industri televisi dan juga dengan mempertimbangkan Jakarta sebagai pusat kekuasaan maupun ekonomi, secara bertahap mulai tahun 1993 sampai dengan 1998, SCTV memindahkan basis operasi siaran nasionalnya dari Surabaya ke Jakarta.

Pada tahun 1999 SCTV melakukan siarannya secara nasional dari Jakarta. Sementara itu, mengantisipasi perkembangan teknologi informasi yang kian mengarah pada konvergensi media SCTV mengembangkan potensi multimedianya dengan meluncurkan situs http://www.liputan6.com, http://www.liputanbola.com, dan http://www.vidio.com. Melalui ketiga situs tersebut, SCTV tidak lagi hanya bersentuhan 
dengan masyarakat Indonesia di wilayah Indonesia, melainkan juga menggapai seluruh dunia. Dalam perkembangan berikutnya, melalui induk perusahaan PT. Surya Citra Media tbk (SCM), SCTV mengembangkan potensi usahanya hingga mancanegara dan menembus batasan konsep siaran tradisional menuju konsep industri media baru.dan kendaraan niaga baik untuk perorangan maupun korporasi.

\section{METODE PENELITIAN}

Dalam penelitian ini, metode yang digunakan adalah deskriptif dengan penyajian data kualitatif. Definisi penelitian kualitatif menurut Sugiyono (2012) adalah penelitian yang digunakan untuk meneliti pada kondisi objek yang alamiah, dimana peneliti adalah sebagai instrument kunci, teknik pengumpulan data dilakukan secara triangulasi, analisis data bersifat induktif, dan hasil penelitian kualitatif lebih menekankan makna daripada generalisasi (Sugiyono, 2010).

Penelitian deskriptif hanya memaparkan situasi dan peristiwa, tidak mencari atau menjelaskan hubungan, tidak menguji hipotesis atau membuat prediksi. Metode deskripsi dirancang untuk mengumpulkan informasi tentang keadaan nyata yang sekarang berlangsung. Tujuan utama dalam menggunakan metode ini adalah untuk menggambarkan sifat suatu keadaan yang sementara berjalan saat penelitian dilakukan dan memeriksa sebab-sebab dari suatu gejala tertentu. Metode deskriptif juga membantu kita mengetahui bagaimana caranya mencapai tujuan yang diinginkan.

Metode deskriptif disini memaparkan situasi atau peristiwa atau penelitian observasional seperti yang dikemukakan oleh Wood. Lebih lanjut, Rakhmat mengemukakan bahwa penelitian deskriptif ditujuan untuk:

Mengumpulkan informasi aktual secara rinci yang melukiskan gejala yang ada; Mengidentifikasikan masalah atau memeriksa kondisi dan praktek-praktek yang berlaku; Membuat perbandingan atau evaluasi; Menentukan apa yang dilakukan orang lain dalam menghadapi masalah yang sama dan belajar dari pengalaman mereka untuk menetapkan rencana dan keputusan pada waktu yang akan datang (Rakhmat, 2012).

Menurut Elvinaro Ardianto dalam bukunya yang berjudul "Metodologi Penelitian untuk Public Relations Kuantitatif dan Kualitatif" menjelaskan bahwa metode deskriptif memiliki ciri sebagai berikut:

"Metode deskriptif menitikberatkan pada observasi dan suasana alamiah (natural setting). Peneliti terjun langsung ke lapangan, bertindak sebagai pengamat. Ia membuat kategori perilaku, mengamati gejala, dan mencatatnya dalam buku observasi. Ia tidak berusaha untuk memanipulasi variabel." (Ardianto, 2011).

Penelitian ini dimaksudkan untuk menggambarkan bagaimana Proses Public Relations oleh Departemen Program Communication dalam Program "Layar Tancap 
Untuk Semua" sebagai upaya meningkatkan awareness kepada masyarakat mengenai SCTV sebagai Rumah Film Indonesia. Pada penelitian ini peneliti menyusun data yang telah dikumpulkan yang berkaitan dengan masalah yang diteliti dan kemudian diklasifikasikan lalu dianalisis secara deskriptif.

\section{HASIL DAN PEMBAHASAN}

\section{Tahap Riset}

Defining the problem terdiri atas dua substansi, yakni the problem dan situational analysis. The problem merupakan tujuan dari Departemen Program Communication SCTV dalam membuat program Layar Tancap Untuk Semua. Dimana tujuannya adalah meningkatkan awareness masyarakat mengenai SCTV sebagai Rumah Film Indonesia dan sebagai lokomotif SCTV dalam mempromosikan Rumah Film Indonesia.

Situational analysis merupakan proses riset yang dilakukan oleh Departemen Program Communication SCTV secara internal dan eksternal. Secara internal, SCTV memiliki kekuatan sebagai stasiun televisi keluarga sehingga dapat menjangkau publiknya secara luas. Tetapi kelemahannya adalah kurangnya SDM yang dimiliki sehingga minimnya analisis situasi di lapangan. Secara eksternal, kurangnya edukasi masyarakat menjadi ancaman bagi SCTV dalam meningkatkan awareness mereka terhadap Rumah Film Indonesia. Namun hal tersebut dapat diatasi dengan peluang yang ada yakni penambahan activity selama kegiatan berlangsung seperti senam massal, kemudian pemilihan materi film yang menjangkau seluruh lapisan masyarakat, desain konsep venue yang menarik, dan penyampaian message yang tepat seperti yang dilakukan ialah menggunakan MC.

Pembahasan pada tahap pertama ini dikaji dengan menggunakan pendekatan proses Public Relations yang dikemukakan oleh Scott M. Cutlip, Allen H. Center, dan Glen M. Broom. Proses Public Relations yang dikemukakan oleh Cutlip, Center, dan Broom yang pertama adalah defining the problem yang dimulai dengan melakukan penilaian tentang adanya sesuatu yang salah atau sesuatu yang seharusnya berjalan dengan lebih baik. Dalam hal terkandung gagasan bahwa tujuan organisasi adalah menyediakan kriteria untuk penilaian tersebut. Pada tahap ini defining the problem mencakup pengkajian dan pemantauan opini, sikap dan perilaku yang terkait dengan tindakan dan kebijakan organisasi.

Tahap ini memberikan landasan bagi tahap-tahap selanjutnya dalam proses penyelesaian masalah, dengan mengatakan “What's happening now?" (Apa yang terjadi sekarang?). Langkah-langkah yang dilakukan pada tahap defining the problem adalah the problem, concern, or opportunity dan situation analysis yang meliputi analisis situasi internal dan eksternal.

Karena Public Relations merupakan fungsi manajemen dalam organisasi, maka aktivitas Public Relations sangat berkaitan dengan aktivitas organisasi, sehingga riset-riset 
Public Relations merupakan bagian dari riset organisasi. Hal ini pula yang dilakukan oleh Departemen Program Communication SCTV sebagai perpanjangan tangan dari Direktorat Programing SCTV.

Karena itu, riset Public Relations pada dasarnya berkaitan dengan upaya mengukur bagaimana opini publik (internal atau eksternal) terhadap perusahaan. Misalnya, bagaimana opini publik terhadap program Layar Tancap Untuk Semua.

Selain itu, untuk meningkatkan awareness masyarakat dalam program Layar Tancap Untuk Semua diperlukan usaha untuk memberikan pengalaman yang special bagi pengunjungnya. Untuk menyentuh sense dan feel pengunjung, dapat dipertimbangkan unsur gerak (Motion), warna (Colour), suara (Sound), dan cahaya (Light). Unsur-unsur ini dapat diterapkan pada dekorasi, lighting, penyusunan layout venue, rundown, penyusunan materi cue card dan pemilihan $\mathrm{MC}$.

Perhatian seseorang merupakan salah satu faktor yang sangat menentukan bagaimana kemudian dia mempersepsi atau menilai pesan yang disampaikan. Perhatian terjadi ketika salah satu atau beberapa indera berkonsentrasi sementara indera yang lain melemah (Pudjiastuti, 2010).

Misalnya gerakan pengisi acara di panggung, warna dekorasi, atau cahaya lampu panggung akan merangsang orang untuk menggunakan penglihatannya, suara musik akan merangsang orang untuk menggunakan pendengarannya, dan sebagainya. Suasana yang diciptakan juga tidak hanya dapat menyentuh indera luar, tetapi juga menyentuh perasaannya. Berdasarkan Perencanaan Program Public Relations menurut Cutlip, Center, dan Broom tersebut ada 4 analisis lingkungan situasi dan kondisi. Peneliti melihat bahwa Departemen Program Communication telah memenuhi hal tersebut.

1. A searching look backward, Departemen Program Communication SCTV sudah menyadari dan mengetahui bagaimana kondisi SCTV semenjak bergabung dengan Indosiar di dalam naungan Emtek. Semenjak bergabung maka kini tugas dari Departemen Program Communication tidak hanya kepada SCTV namun juga kepada Indosiar.

2. A deep look inside, Departemen Program Communication SCTV menyadari apa yang menjadi perhatian mereka dan masyarakat dalam programprogram SCTV. Dimana kini programprogram SCTV bermuara pada film, khususnya film nasional, sehingga meneguhkan SCTV sebagai Rumah Film Indonesia.

3. A wide look around, situasi saat ini dimana masih banyak masyarakat yang di daerahnya belum memiliki gedung bioskop. Hal itu menjadi kesempatan bagi SCTV untuk lebih mendekatkan diri kepada masyarakat dimana masyarakat yang sesungguhnya merupakan pemirsa setia SCTV. 
4. A long, long look ahead, program Layar Tancap Untuk Semua ini dampaknya tidak akan dirasakan sekarang. Tetapi dampaknya akan bergulir seperti efek bola salju dimana nanti ujungnya adalah meningkatnya awareness masyarakat mengenai SCTV sebagai Rumah Film Indonesia.

Dalam unsur analisis situasi, hal yang penting diperhatikan adalah kelemahan, kekuatan lembaga, serta peluang dan kesempatan yang dimiliki lembaga. Dalam hal ini kelemahan dari Departemen Program Communication SCTV adalah belum menyeluruhnya analisis situasi yang dilakukan karena kurangnya SDM. Kekuatan dari Departemen Program Communication SCTV adalah citra SCTV sebagai stasiun televisi keluarga sehingga dekat dengan seluruh kalangan masyarakat. Peluang dan kesempatan yang dimiliki Departemen Program Communication dalam program Layar Tancap Untuk Semua adalah penambahan activity, materi film yang ditayangkan, serta desain konsep yang lebih menarik perhatian masyarkat serta penyampaian message kepada masyarakat mengenai SCTV sebagai Rumah Film Indonesia.

\section{Tahap Perencanaan}

Planning and Programing terdiri atas tiga substansi, yakni Target Publics, Objective, dan Proses Perencanaan dan Pemrograman.

Target Publics menjabarkan bahwa masyarakat umum sebagai target dari
Departemen Program Communication SCTV dalam membuat program Layar Tancap Untuk Semua. Dimana Program Goal atau tujuan dari dibuatnya program Layar Tancap Untuk Semua adalah meningkatkan awareness masyarakat terhadap SCTV sebagai Rumah Film Indonesia dan mendekatkan diri dari SCTV kepada masyarakat sebagai pemirsa setia SCTV.

Objective dari dibuatnya program Layar Tancap Untuk Semua yaitu meningkatkan minat masyarakat untuk menonton film nasional, apresiasi terhadap SCTV meningkat, dan mendapatkan kesan positif dari masyarakat yang dapat menjadi bola salju bagi programprogram SCTV yang akan datang.

Proses perencanaan dan pemrograman yang dilakukan oleh Departemen Program Communication SCTV adalah menyusun tema festival untuk program Layar Tancap Untuk Semua dimana temanya adalah festival layar tancap. Kemudian menyusun sistematika pelaksanaan dan rundown yang terdapat di lampiran. Menyusun anggaran dan berkoordinasi juga dengan Departemen Marketing Communication mengenai pihak sponsor acara. Berkoordinasi dengan pihak Event Organizer untuk pelaksanaan di lapangan. Terakhir ialah control teknis di lapangan selama berjalannya acara.

Program goal adalah langkah pertama yang dilakukan dalam strategi perencanaan. Langkah ini membantu membangun tujuan yang jelas. Penetapan tujuan dari program yang dijalankan sejalan dengan tujuan organisasi. 
Menetapkan tujuan sangat penting agar program yang direncanakan memiliki arah dan dapat menunjukkan suatu keberhasilan tertentu.

Dalam program Layar Tancap Untuk Semua tujuan yang ingin dicapai melalui kegiatan ini adalah meningkatkan awareness masyarakat terhadap SCTV sebagai Rumah Film Nasional. Sedangkan tujuan khusus dari program Layar Tancap Untuk Semua ini adalah mendekatkan diri dari SCTV kepada masyarakat sebagai pemirsa setia SCTV.

Dalam program Layar Tancap Untuk Semua peneliti melihat bahwa upaya yang dilakukan oleh Departemen Program Communication termasuk ke dalam tugas utama Humas yaitu meningkatkan citra yang positif, dimana dalam hal ini adalah meningkatkan awareness kepada masyarakat mengenai SCTV sebagai Rumah Film Indonesia.

Target publik dalam program Layar Tancap Untuk Semua merupakan masyarakat yang di daerahnya belum memiliki gedung bioskop. Pertimbangan khalayak dalam suatu perencanaan program menjadi hal yang sangat penting. Dalam hal ini Departemen Program Communication sudah memiliki pertimbangan yang cukup matang mengenai siapa publik sasaran yang mereka tuju.

Dalam program Layar Tancap Untuk Semua sasaran yang hendak dicapai pada setiap publik sasaaran program untuk mencapai tujuan program adalah meningkatkan minat masyarakat untuk menonton film nasional. Selain itu, dengan diadakannya program Layar Tancap Untuk Semua, respon masyarakat positif dan apresiasi mereka terhadap SCTV semakin meningkat. Kesan positif dari masyarakat ini yang dapat menjadi efek bola salju bagi SCTV.

Dalam menjangkau publik sasarannya Departemen Program Communication SCTV menyadari bahwa tingkat kehadiran pengunjung di lokasi dapat menjadi hambatan. Oleh karena itu Departemen Program Communication SCTV menanggulanginya dengan menyusun rundown yang tepat sehingga rangkaian kegiatan yang dimulai dari sore hari sudah diisi dengan activity yang mengundang massa yakni lomba senam massal. Kemudian setelahnya diisi dengan hiburan musik oleh artis lokal. Lalu setelah break Maghrib diadakan games dan pembagian doorprize yang bertujuan untuk menarik lagi crowd yang mungkin saja berkurang karena break Maghrib. Kreativitas penyusunan activity dan gimmick diperlukan oleh Departemen Program Communication untuk tetap menarik perhatian pengunjung di lokasi hingga puncak acara yakni pertunjukan layar tancap.

Kegiatan promosi program Layar Tancap Untuk Semua juga menjadi salah satu fokus kegiatan dari pelaksanaan program oleh Departemen Program Communication SCTV. Mereka membuat berbagai materi promosi mulai dari off-air seperti T-Banner, spanduk, dan flyer. Kemudian juga dari on-air yakni penayangan running text dan sounding dari host Inbox Carnaval SCTV. Selain itu Departemen Program Communication juga membuat mobil woro-woro untuk mempromosikan program Layar Tancap Untuk Semua di H-1 dengan 
berkeliling ke permukiman penduduk di sekitar lokasi kegiatan.

\section{Tahap Pelaksanaan}

Taking and communication terdiri atas tiga substansi, yaitu action strategies, communication strategies, dan program implementation plans. Dalam action strategies, adalah pelaksanaan secara teknis apa saja yang dilakukan oleh Departemen Program Communication SCTV dalam program Layar Tancap Untuk Semua ini, yaitu publikasi dan promosi baik secara below the line dan on-air, pelaksanaan kegiatan di lapangan sesuai rundown, dan dokumentasi kegiatan di lapangan selama acara berlangsung.

Pada susbtansi

communication

strategies, Departemen

Program

Communication SCTV membuat isi pesan SCTV sebagai Rumah Film Indonesia di dalam media promosi yang digunakan juga di dalam materi cue card yang dibacakan oleh MC. Kemudian pemilihan media apa saja yang digunakan untuk program Layar Tancap Untuk Semua, yakni media layar tancap untuk pemutaran film, kemudian spanduk dan baligho untuk media promosi di lapangan, juga bekerjasama dengan media partner yakni radio lokal dan koran lokal setempat.

Substansi yang terakhir ialah program implementation plans, yakni pihak-pihak yang terlibat dalam program Layar Tancap Untuk Semua. Selain Departemen Program Communication SCTV, juga melibatkan Departemen Marketing Communication SCTV dan Event Organizer. Kemudian waktu dan tempat pelaksanaan program Layar Tancap Untuk Semua yang dilaksanakan di Lapangan Cangkol, Sukoharjo, Jawa Tengah pada Sabtu, 9 Desember 2017 dari pukul 15.00 WIB hingga pukul 22.00 WIB dengan rangkaian kegiatan mengikuti rundown yang terlampir.

Dalam sebuah program strategi aksi merupakan hal yang sangat penting. Strategi aksi ini menyangkut bagaimana aksi yang kita lakukan untuk mencapai tujuan yang telah dirancang. Dalam program Layar Tancap Untuk Semua aksi-aksi atau kegiatan yang dilakukan adalah dengan melaksanakan rangkaian acara yang mengundang massa yakni lomba senam massal. Kemudian setelahnya diisi dengan hiburan musik oleh artis lokal. Lalu setelah break Maghrib diadakan games dan pembagian doorprize yang bertujuan untuk menarik lagi crowd yang mungkin saja berkurang karena break Maghrib. Kreativitas penyusunan activity dan gimmick diperlukan oleh Departemen Program Communication untuk tetap menarik perhatian pengunjung di lokasi hingga puncak acara yakni pertunjukan layar tancap.

Strategi Public Relations harus mempertimbangkan cara-cara yang dapat mengintegrasikan semua aktivitasnya, dan cara yang paling praktis serta definitif adalah mendasarkan program Layar Tancap Untuk Semua pada analisis audiens. Memahami teori dan praktik hubungan konsumen untuk menjual sesuatu sama pentingnya dengan memahami apa yang ingin diketahui oleh audiens dan 
stakeholder yang berbeda-beda, yang dari merekalah respons atau sebuah pesan berasal, sehingga prinsip-prinsip saling memahami dapat diterapkan.

Strategi aksi merupakan bagian utama dari program tetapi hanya sebagian dari seluruh program Public Relations yang terlihat di permukaan. Komunikasi, yang biasanya merupakan komponen yang lebih tampak, berfungsi untuk menginterpretasikan dan mendukung strategi aksi. Komunikasi yang efektif harus didesain agar sesuai dengan situasi, waktu, tempat dan audiens. Ini berarti pemilihan media dan teknik harus benar.

Isi pesan yang disampaikan dalam program Layar Tancap Untuk Semua disesuaikan dengan substansi yang telah dirumuskan selama perencanaan. Isi pesan yang disampaikan sangatlah berpengaruh. Isi pesan yang diberikan haruslah sesuai, seperti yang disampaikan Cutlip, Center, dan Broom bahwa pesan harus sesuai dengan kapasitas pemahaman penerima dan relevan dengan kepentingan atau kebutuhan penerima. Terakhir pesan harus memotivasi kepentingan penerima dan menimbulkan respon (Cutlip et al., 2011).

Pada program Layar Tancap Untuk Semua komunikator yang dihadirkan adalah MC selama acara berlangsung. Sementara untuk materi cue card MC disusun oleh Departemen Program Communication SCTV berkolaborasi dengan Event Organizer dan Departemen Marketing Commnunication SCTV untuk mengakomodir benefit sponsor. Peneliti telah mendapatkan dokumen cue card $\mathrm{MC}$ dalam pelaksanaan program Layar Tancap Untuk
Semua di Sukoharjo, Jawa Tengah yang peneliti masukkan di lampiran.

Namun selama observasi di lapangan, peneliti melihat bahwa pesan yang disampaikan oleh MC mayoritas adalah sounding mengenai benefit sponsor. Pesan SCTV sebagai Rumah Film Indonesia sangat minim untuk disampaikan oleh MC. Sehingga pesan yang disampaikan bahwa SCTV sebagai Rumah Film Indonesia hanya tersirat melalui desain konsep lokasi, media promosi, dan pertunjukan layar tancap itu sendiri.

Menurut Chaffee, media banyak mengandung isi berita sedangkan rekan personal kemungkinan punya pengalaman 'konsumen' yang relevan. Karena konsumsi sebagian adalah persoalan mendefinisikan 'diri' sosial seseorang maka orang lain akan mampu untuk memberikan pedoman sosial normatif untuk pola konsumsi yang tidak bisa disediakan oleh media. Terkahir beberapa persoalan mungkin tidak dibahas media massa secara mendalam untuk memenuhi kebutuhan informasi personal (Cutlip et al., 2011).

Media yang digunakan dalam program Layar Tancap Untuk Semua selain media layar tancap itu sendiri adalah berbagai materi promosi mulai dari off-air seperti T-Banner, spanduk, dan flyer. Kemudian juga dari on-air yakni penayangan running text dan sounding dari host Inbox Carnaval SCTV. Selain itu Departemen Program Communication juga membuat mobil woro-woro untuk mempromosikan program Layar Tancap Untuk Semua di H-1 dengan berkeliling ke 
permukiman penduduk di sekitar lokasi kegiatan.

Pihak-pihak yang terlibat dalam program Layar Tancap Untuk Semua adalah Departemen Program Communication SCTV di bawah Direktorat Programing SCTV. Kemudian juga berkolaborasi dengan Event Organizer untuk teknis di lapangan dan dengan Departemen Marketing Communication SCTV untuk hal benefit sponsor. Untuk pihak eksternal, Departemen Program Communication SCTV bekerja sama dengan Pemerintah Daerah setempat dan Kepolisian untuk hal perizinan, Radio Lokal sebagai media partner, dan pihak Sponsor.

Pelaksanaan secara sistematis telah diuraikan peneliti dalam pembahasan sebelumnya namun secara umum program Layar Tancap Untuk Semua diadakan selama 1 hari mulai pukul 15.00 WIB hingga pukul 22.00 WIB. Adapun rangkaian kegiatan di dalam program Layar Tancap Untuk Semua adalah lomba senam massal. Kemudian setelahnya diisi dengan hiburan musik oleh artis lokal. Lalu setelah break Maghrib diadakan games dan pembagian doorprize hingga puncak acara yakni pertunjukan layar tancap.

\section{Tahap Evaluasi}

Evaluating the Program memiliki dua substansi yaitu evaluation dan feedback and program adjustment. Substansi evaluation menjabarkan tahapan evaluasi yang dilakukan oleh Departemen Program Communication SCTV selama dan setelah pelaksanaan program
Layar Tancap Untuk Semua. Pertama adalah mengukur tingkat kehadiran pengunjung. Kedua adalah melihat tingkat partisipasi pengunjung yang hadir dengan pengundian doorprize. Ketiga adalah melihat respon masyarakat terhadap program Layar Tancap Untuk Semua di social media. Keempat adalah melihat efek dari program Layar Tancap Untuk Semua dengan melihat share rating program SCTV tentang film Indonesia. Terakhir adalah melakukan random survey kepada pengunjung yang hadir di lokasi.

Pada feedback and program adjustment, Departemen Program Communication SCTV membuat laporan hasil pelaksanaan program Layar Tancap Untuk Semua yang diserahkan kepada Direktorat Programing SCTV dan didiskusikan dalam meeting bersama juga dengan Departemen Marketing Communication SCTV. Kemudian Departemen Program Communication SCTV menyusun proposal program Festival 28 sebagai pengembangan dari program Layar Tancap Untuk Semua.

Tahap evaluasi ini merupakan tahap terakhir dalam proses Public Relations menurut Scott M. Cutlip, Allen H. Center, dan Glen M. Broom. Dalam hal ini peneliti melihat bahwa Departemen Program Communication SCTV belum menjalankan dengan baik. Tahap evaluasi belum terlaksana dengan baik karena proses evaluasi yang utama hanya dilakukan melalui tolak ukur tingkat kehadiran pengunjung. 
Menurut Ruslan (1995), dalam tahap evaluasi Public Relations mengidentifikasi atau menganalisis hasil akhir atau evaluasi, yakni lebih bersifat checkpoint satu per satu dari komponen atau tahapan-tahapan perencanaan dan penggiatan sudah berjalan atau belum. Yang terlihat apakah semua komponen rencana dan kegiatan tersebut sudah berjalan sebagaimana mestinya. Hasil evaluasi dapat memberi gambaran apakah secara kuantitatif dan kualitatif bahwa program sudah memenuhi persyaratan atau masih terjadi kekuarangan. Aktivitas diteliti dan dianalisis secara saksama dari berbagai persoalan atau pihak yang terlibat, kemudian ditarik suatu kesimpulan tentang sukses atau tidaknya perencanaan dan penggiatan tersebut. Kalau terjadi hambatan serta kegagalan bisa dilihat dari salah satu komponen yang kurang berfungsi dengan baik atau tidak berjalan sesuai dengan yang direncanakan (Ruslan, 2012).

Kunci utama untuk mengevaluasi apa yang dipelajari orang dari suatu program (atau sumber yang bersamaan) adalah dengan mengukur variabel pengetahuan, kesadaran dan pemahaman sebelum program dimulai untuk menentukan perubahan harus dibuat perbandingan antar setidaknya dua ukuran yang dapat dibandingkan, jumlah orang yang mengubah sikapnya, jumlah orang yang bertindak sesuai dengan keinginan (Cutlip et al., 2011).

Menurut Frank Jefkins dalam buku Public Relations (2003), ada beberapa metode pengukuran: Berdasarkan tingkat liputan; Berdasarkan data statistik peringkat dan jumlah khalayak; Evaluasi berdasarkan sumber; Pengumpulan pendapat; Evaluasi berdasarkan umpan balik statistik secara langsung; Umpan balik media; Pengukuran tingkat pemahaman; Hasil-hasil yang diinginkan (Jefkins, 2003).

Evaluasi dalam program Layar Tancap Untuk Semua hanya dilakukan sebatas mengukur tingkat kehadiran pengunjung dan tidak melakukan teknik evaluasi lainnya.

\section{SIMPULAN}

Berdasarkan hasil penelitian proses Public Relations dalam program Layar Tancap Untuk Semua oleh Departemen Program Communication SCTV:

Pada tahap Riset, analisis situasi yang dilakukan Departemen

Program Communication adalah analisis situasi secara internal dimana SCTV sebagai stasiun televisi yang rutin menayangkan film-film Indonesia menjadi alasan dibuatnya program Layar Tancap Untuk Semua. Dengan demikian pembuatan program Layar Tancap Untuk Semua sesuai dengan tujuan Departemen Program Communication SCTV sebagai upaya meningkatkan awaraness kepada masyarakat mengenai SCTV sebagai Rumah Film Nasional. Program Layar Tancap Untuk Semua merupakan sebuah strategi yang dilakukan untuk meningkatkan awareness kepada masyarakat mengenai SCTV sebagai Rumah Film Nasional. Proses riset yang dilakukan mungkin sangat sederhana yaitu sebatas diskusi. Proses lebih rinci dan mendalam bagaimana konsep ini akhirnya mengkristal dan jelasnya sulit untuk peneliti cari lebih jauh karena proses 
riset yang dilakukan sangat sederhana dan tertutup.

Pada tahap Perencanaan, Departemen Program Communication SCTV melakukan perencanaan dengan baik. Dalam program Layar Tancap Untuk Semua tujuan yang ingin dicapai melalui kegiatan ini adalah meningkatkan awareness masyarakat terhadap SCTV sebagai Rumah Film Nasional. Sedangkan tujuan khusus dari program Layar Tancap Untuk Semua ini adalah mendekatkan diri dari SCTV kepada masyarakat sebagai pemirsa setia SCTV. Adapun sasaran utama dalam program Layar Tancap Untuk Semua adalah masyarakat umum yang mana mereka merupakan arti sesungguhnya dari pemirsa setia SCTV. Secara khusus, masyarakat yang menjadi sasaran utama adalah mereka yang di daerahnya belum memiliki gedung bioskop. Waktu pelaksanaan pun menjadi bagian dari proses planning and programing. Adapun waktu pelaksanaan program Layar Tancap Untuk Semua bergulir setiap bulan roadshow ke setiap kabupaten/kota yang tidak memiliki gedung bioskop selama dalam kurun waktu dua tahun terakhir ini, yakni dari tahun 2016 hingga tahun 2017.

Pada tahap Pelaksanaan, Departemen Program Communication SCTV melakukannya dengan baik berkoordinasi dengan Event Organizer dan Departemen Marketing Communication. Program Layar Tancap Untuk Semua dilaksanakan selama 1 hari dimulai dari sore hari pukul 15.00 WIB hingga pukul 22.00
WIB. Tema yang diangkat adalah festival dengan puncak acara pertunjukan layar tancap. Adapun agenda kegiatannya secara umum tidak berbeda setiap bulannya karena sudah mengikuti rundown yang telah disusun. Pada program Layar Tancap Untuk Semua komunikator yang dihadirkan adalah MC selama acara berlangsung. Sementara untuk materi cue card MC disusun oleh Departemen Program Communication SCTV berkolaborasi dengan Event Organizer dan Departemen Marketing Commnunication SCTV untuk mengakomodir benefit sponsor. Media yang digunakan dalam program Layar Tancap Untuk Semua selain media layar tancap itu sendiri adalah berbagai materi promosi mulai dari offair seperti T-Banner, spanduk, dan flyer. Kemudian juga dari on-air yakni penayangan running text dan sounding dari host Inbox Carnaval SCTV. Selain itu Departemen Program Communication juga membuat mobil woro-woro untuk mempromosikan program Layar Tancap Untuk Semua di H-1 dengan berkeliling ke permukiman penduduk di sekitar lokasi kegiatan.

Pada tahap Evaluasi, Departemen Program Communication belum melakukan dengan baik karena proses evaluasi hanya dilakukan dengan mengukur kehadiran pengunjung baik yang stay maupun yang in-out, Departemen Program Communication juga melakukan evaluasi dari tingkat interest pengunjung yang hadir dengan pengundian doorpize. Kemudian melihat respon dari 
masyarakat di social media. Lalu melihat share rating program SCTV tentang film Indonesia. Terakhir adalah melakukan random survey dengan pengunjung yang hadir di lokasi. Juga dapat disimpulkan bahwa program Layar Tancap Untuk Semua belum dapat meningkatkan awareness masyarakat sesuai yang diharapakan dalam proses Riset ketika pertama kali program ini didiskusikan. Karena hasil observasi di lapangan tidak didapatnya upaya yang dilakukan oleh Departemen Program Communication SCTV untuk meningkatkan awareness masyarakat terhadap SCTV sebagai Rumah Film Indonesia. Sebagai contoh, MC hanya menyebutkan satu kali ajakan untuk menonton film nasional di SCTV karena SCTV adalah Rumah Film Indonesia.

Adapun saran yang diberikan peneliti untuk proses Public Relations pada program Layar Tancap Untuk Semua oleh Departemen Program Communication adalah: Analisis situasi yang dilakukan tidak hanya melihat secara internal tetapi juga secara eksternal. Proses riset sebaiknya tidak hanya dilakukan dengan sebatas diskusi, tetapi juga bisa dilakukan dengan setiap pernyataan masalah berisi ukuran konkrit dari situasi masalah berdasarkan penelitian yang obyektif.

Penyusunan cue card dan rundown ditambahkan lagi konten mengenai pesan SCTV sebagai Rumah Film Indonesia agar semakin meningkatkan awareness masyarakat. Evaluasi yang dilakukan dengan menggunakan metode yang memiliki output lebih terukur seperti survey dengan kuisioner untuk melihat keberhasilan program apakah tujuan yang ingin dicapai sudah tercapai atau belum.

\section{DAFTAR PUSTAKA}

Ardianto, E. (2011). Metode Penelitian untuk Public Relations. Bandung: Simbiosa Rekatama Media.

Cutlip, S. M., Center, A. H., \& Broom, G. M. (2011). Effective Public Relations. Jakarta: Kencana Prenadamedia Group.

Handayani, D. (2010). The Official Mim Academy Coursebook Brand Operation. Esensi.

Jefkins, F. (2003). Public Relations. Jakarta: Erlangga.

Pudjiastuti, W. (2010). Special Event: Alternatif Jitu Membidik Pasar. Jakarta: PT. Elex Media Komputindo.

Rakhmat, J. (2012). Metode Penelitian Komunikasi: Dilengkapi Contoh Analisis Statistik. Bandung: Remaja Rosdakarya. Ruslan, R. (2012). Manajemen Public Relations dan Media Komunikasi. Jakarta: Raja Grafindo Persada.

Sugiyono. (2010). Metode Penelitian Kuantitatif, Kualitatif, dan R\&D. Bandung: Alfabeta. 